\title{
Mixtures of Plant Growth-Promoting Rhizobacteria Enhance Biological Control of Multiple Cucumber Pathogens
}

\author{
Georg S. Raupach and Joseph W. Kloepper
}

Department of Plant Pathology, Alabama Agriculture Experiment Station, and Biological Control Institute, Auburn University, Auburn, AL 36849-5409.

Accepted for publication 21 July 1998.

\begin{abstract}
Raupach, G. S., and Kloepper, J. W. 1998. Mixtures of plant growthpromoting rhizobacteria enhance biological control of multiple cucumber pathogens. Phytopathology 88:1158-1164.

Plant growth-promoting rhizobacteria (PGPR) strains INR7 (Bacillus pumilus), GB03 (Bacillus subtilis), and ME1 (Curtobacterium flaccumfaciens) were tested singly and in combinations for biological control against multiple cucumber pathogens. Investigations under greenhouse conditions were conducted with three cucumber pathogens-Colletotrichum orbiculare (causing anthracnose), Pseudomonas syringae pv. lachrymans (causing angular leaf spot), and Erwinia tracheiphila (causing cucurbit wilt disease) - inoculated singly and in all possible combinations. There was a general trend across all experiments toward greater suppression and

mixtures. The same three PGPR strains were evaluated as seed treatments in two field trials over two seasons, and two strains, IN26 (Burkholderia gladioli) and INR7 also were tested as foliar sprays in one of the trials. In the field trials, the efficacy of induced systemic resistance activity was determined against introduced cucumber pathogens naturally spread within plots through placement of infected plants into the field to provide the pathogen inoculum. PGPR-mediated disease suppression was observed against angular leaf spot in 1996 and against a mixed infection of angular leaf spot and anthracnose in 1997. The three-way mixture of PGPR strains (INR7 plus ME1 plus GB03) as a seed treatment showed intensive plant growth promotion and disease reduction to a level statistically equivalent to the synthetic elicitor Actigard applied as a spray.
\end{abstract} enhanced consistency against multiple cucumber pathogens using strain

In response to environmental and health concerns about extended use of pesticides, there is considerable interest in finding alternative control approaches for use in integrated pest management strategies for crop diseases (36). It seems inevitable that fewer pesticides will be used in the future and that greater reliance will be placed on biological technologies including the use of microorganisms as antagonists (15). However, microorganisms as biological control agents typically have a relatively narrow spectrum of activity compared with synthetic pesticides $(3,20)$ and often exhibit inconsistent performance in practical agriculture, resulting in limited commercial use of biocontrol approaches for suppression of plant pathogens (1).

Most approaches for biocontrol of plant diseases have used single biocontrol agents as antagonists to a single pathogen (47). This may partially account for the reported inconsistent performance by biocontrol preparations, because single biocontrol agents are not likely to be active in all soil environments in which they are applied or against all pathogens that attack the host plant. Control of a wide spectrum of pathogens by applied antagonists largely remains an unfulfilled goal for biological control. There are three main approaches to achieve this goal: (i) modify the genetics of the biocontrol agent to add mechanisms of disease suppression that are operable against more than one pathogen, (ii) alter the environment to favor the biological control agent and to disfavor competitive microflora, and (iii) develop strain mixtures with superior biocontrol activity (19). Several strategies for forming mixtures of biocontrol agents could be envisioned including mixtures of organisms with differential plant colonization patterns; mixtures of antagonists that control different pathogens; mixtures of antagonists with different mechanisms of disease suppression; mixtures of taxonom-

Corresponding author: J. W. Kloepper; E-mail: jkloeppe@acesag.auburn.edu

Publication no. P-1998-0825-01R

(C) 1998 The American Phytopathological Society
Additional keywords: biocontrol, Cucumis sativus. ically different organisms; or mixtures of antagonists with different optimum temperature, $\mathrm{pH}$, or moisture conditions for plant colonization.

It is likely that most cases of naturally occurring biological control result from mixtures of antagonists, rather that from high populations of a single antagonist. For example, mixtures of antagonists are considered to account for protection with disease-suppressive soils $(26,38)$. Consequently, application of a mixture of introduced biocontrol agents would more closely mimic the natural situation and might broaden the spectrum of biocontrol activity, enhance the efficacy and reliability of control (12), and allow the combination of various mechanisms without the need for genetic engineering (19).

Previous studies on combinations of biological control agents for plant diseases have included mixtures of fungi $(5,8-10,32)$, mixtures of fungi and bacteria $(11,12,17,19,20,24-26,31)$, and mixtures of bacteria $(10,21,22,28,33,34,37,39,41,42,44,46)$. Most of these reports on mixtures of biocontrol agents showed that combining antagonists resulted in improved biocontrol. However, there also are reports of combinations of biological control agents that do not result in improved suppression of disease compared with the separate antagonists $(7,18,30,40)$. Incompatibility of the coinoculants can arise because biocontrol agents may also inhibit each other as well as the target pathogen or pathogens (24). Thus, an important prerequisite for successful development of strain mixtures appears to be the compatibility of the coinoculated microorganisms $(2,10)$.

In most of the investigations conducted so far, the efficacy of individual biocontrol strains or strain combinations was assessed by screening these agents against a single isolate of the target pathogen. This could be another reason why selected biocontrol agents fail to be commercially successful, because often there is no consideration of the genetic diversity of the target pathogen (28). Little emphasis has been placed on identifying the potential effects of pathogen diversity on the efficacy of biological control agents. Significant genotypic variation in a fungal pathogen population may exist among geographic regions, within a given field, or even 
among lesions on the same plant $(4,13,29)$. In addition, classical selection of biocontrol agents has focused on a single target pathogen and has not accounted for nontarget pathogens causing diseases on the host plants.

The overall goal of this investigation was to determine if improved efficacy and enhanced biological control consistency against multiple pathogens can be achieved by applying a combination of plant growth-promoting rhizobacteria (PGPR) strains, emphasizing strains that induce systemic resistance $(35,45)$. The specific objectives were to test the potential of PGPR strain combinations for enhancing consistency and level of biocontrol against three pathogens and to evaluate the efficacy of PGPR mixtures in the field.

\section{MATERIALS AND METHODS}

Bacterial cultures. PGPR used in this study included Bacillus pumilus strain INR7, Curtobacterium flaccumfaciens strain ME1, Burkholderia gladioli strain IN26, and Bacillus subtilis strain GB03. Strain INR7 produced induced systemic resistance (ISR) in cucumber to anthracnose, angular leaf spot (44), and cucumber mosaic virus (CMV) (35), and strains ME1 and IN26 had ISR activity in nonpublished field trials with cucumber (G. Wei, unpublished data). Strain GB03, which has reported biological control activity against Rhizoctonia solani and Fusarium spp. (1) and which is part of a commercial product (Kodiak; Gustafson Inc., Dallas, TX), was provided as a wettable powder formulation by Gustafson Inc. For long-term storage, cultures were maintained at $-80^{\circ} \mathrm{C}$ in tryptic soy broth (TSB; Difco Laboratories, Detroit, MI) that contained 20\% glycerol. For PGPR seed treatment, vegetative cells grown on tryptic soy agar (TSA) for $24 \mathrm{~h}$ were suspended in $0.02 \mathrm{M}$ phosphate buffer, $\mathrm{pH} 7.0$, and an equal volume of $2 \%$ methylcellulose was then added. The bacterial suspension was mixed with cucumber seeds, resulting in $5 \times 10^{8}$ to $1 \times 10^{10} \mathrm{CFU}$ per seed, and then air-dried overnight in a laminar flow hood. Seed treatments with single strains resulted in population densities of $10^{8}$ to $10^{9} \mathrm{CFU}$ per seed, and strain mixtures in which each strain was applied in equal amounts yielded $10^{9}$ to $10^{10} \mathrm{CFU}$ per seed. With all strain GB03 applications, a slurry of the wettable powder formulation Kodiak was prepared and then applied to cucumber seeds to yield mean densities of $5 \times 10^{9} \mathrm{CFU}$ per seed.

Greenhouse study. A series of greenhouse experiments was conducted to assess control by PGPR against multiple pathogens, using the susceptible cucumber (Cucumis sativus L.) cultivar Straight 8. Treatments were arranged in a randomized complete block design with eight replications consisting of single plants per treatment. A total of nine treatments for each experiment were used for each study: three treatments consisting of single PGPR strains (INR7, ME1, and GB03); three treatments consisting of strain mixtures (INR7 plus ME1; INR7 plus GB03; and INR plus ME1 plus GB03); and three controls (a nonbacterized but pathogen-challenged disease; a nontreated healthy control; and a classical ISR control in which plant resistance was induced with the pathogen Colletotrichum orbiculare applied to the cotyledons 7 days prior to challenge).

Cucumber seeds were planted to a depth of approximately $1 \mathrm{~cm}$ in $10-\mathrm{cm}^{2}$ plastic pots (one seed per pot) containing $500 \mathrm{~cm}^{3}$ of soilless Pro-Mix growing medium (Premier Peat Ltd., Rivière-du Loup, Québec, Canada) and kept in the greenhouse with daily watering. Pathogens used for the challenge inoculation were $C$. orbiculare, causal agent of anthracnose disease, Pseudomonas syringae pv. lachrymans, causal agent of angular leaf spot, and Erwinia tracheiphila, causal agent of cucurbit wilt.

Inoculum of $C$. orbiculare was prepared by suspending spores from an 8-day-old culture grown on green bean agar (14) in sterile water to give a concentration of $10^{5}$ spores per ml. Inoculum of $P$. syringae pv. lachrymans was prepared by suspending cells from a 24-h culture grown on TSA in distilled water to give a concentration of $10^{9} \mathrm{CFU} / \mathrm{ml}$. Inoculum of E. tracheiphila was prepared by grinding cucumber stem pieces infected with the cucumber wilt pathogen.
C. orbiculare and $P$. syringae pv. lachrymans were sprayed onto entire plants using a backpack $\mathrm{CO}_{2}$ sprayer (model D-2015; R \& D Sprayers, Opelousas, LA) and sprayed to run-off, and E. tracheiphila was injected $(0.1$ to $0.2 \mathrm{ml})$ with a syringe into the petiole of the first leaf.

A total of seven different experiments were conducted. Plants in each experiment were challenged with a single, double, or triple combination of pathogens 18 days after planting (DAP), and each experiment was repeated three times. All plants from experiments using $C$. orbiculare as the challenge pathogen were placed into a humidity chamber for $36 \mathrm{~h}$ immediately after inoculation. Seven days after pathogen challenge, the second and third leaf of each plant was assessed for anthracnose and angular leaf spot diseases, and the percent diseased leaf area of each was recorded. Cucurbit wilt was rated as the number of wilted leaves per total leaf number of each plant over an average of nine consecutive observation days; the disease progress was determined by measuring the area under the disease progress curve (AUDPC) as described by Tooley and Grau (43). Because of different amounts of disease in each experiment and heterogeneity of variances, data from three repeated trials were not combined, and one representative experiment from each series is presented. Data were analyzed with the general linear models procedure (GLM) in PC-SAS (SAS Institute, Cary, NC), and treatment means were separated using the least significance difference (LSD) test at $P=0.05$.

Field trials. Two field trials were conducted at the E. V. Smith Horticulture Substation near Shorter, AL, with cucumber seeds from cultivar Straight 8 direct-seeded by hand-planting at 1-m spacing between plants in the field. In 1996, to evaluate control under two different disease pressures, a paired-plot design arranged in randomized complete blocks was used. One pair of each plot had source plants and the other did not; each pair consisted of a single row (replication) of eight plants. A total of eight treatments, each replicated six times with eight plants per replication, was used. Seed treatments consisted of the three PGPR strains INR7, ME1, and GB03, alone and in all possible combinations, plus a nonbacterized control. The same seed treatment procedure as described for the greenhouse study was used. Source plants were grown in the greenhouse without PGPR and were inoculated 1 week prior to transplanting to the field either with the two-leaf pathogens causing anthracnose and angular leaf spot or with the pathogen causing cucurbit wilt disease, and two of each were transplanted into experimental plots 21 DAP, after the plot was seeded. Disease on the direct-seeded cucumber plants (noninoculated plants) was monitored in both the plot pairs with and without inoculated source plants at 45 DAP by recording the number of leaves showing more than five lesions of angular leaf spot, which was the only disease in 1996. Marketable cucumber fruit were picked every 2 or 3 days until the end of the growing season, and cumulative weight was recorded.

In the second trial, conducted in 1997, the efficacy of PGPR treatments under high disease pressure created through source plants infected with anthracnose, angular leaf spot, and cucurbit wilt and then transplanted into experimental plots 21 DAP was investigated. The source plants were prepared as in 1996. The experiment was arranged in a randomized complete block design with eight treatments replicated six times and eight plants per replication. Treatments included strains INR7 and IN26 applied alone or in combination as a seed coat; spray application of each strain, INR7 and IN26, alone; a mixture of strains INR7, ME1, and GB03 applied as a seed coat; a positive control consisting of a spray application of the synthetic chemical Actigard (Novartis Crop Protection, Inc., Basel, Switzerland), the first commercial elicitor product with ISR activity; and a nontreated control. All spray applications were first applied 28 DAP and then again three more times at weekly intervals, each time spraying entire plants to run-off using rates of $10^{8}$ $\mathrm{CFU} / \mathrm{ml}$ for bacteria and $50 \mathrm{mg} / \mathrm{liter}$ for Actigard. Main runner length of cucumber plants was measured at 43 DAP, and a disease index was determined at 49 DAP according to a disease rating 
TABLE 1. Disease protection induced by three plant growth-promoting rhizobacteria (PGPR) strains and their mixtures after single-pathogen challenge of cucumber plants under greenhouse conditions ${ }^{\mathrm{v}}$

\begin{tabular}{lccc}
\hline Treatments $^{\mathrm{w}}$ & $\begin{array}{c}\text { Colletotrichum } \\
\text { orbiculare }^{\mathrm{x}}\end{array}$ & $\begin{array}{c}\text { Pseudomonas syringae } \\
\text { pv. }\end{array}$ & $\begin{array}{c}\text { Erwinia } \\
\text { tracheiphila }^{\mathrm{y}}\end{array}$ \\
\hline Disease control & $75.9 \mathrm{a}^{\mathrm{z}}$ & $127.9 \mathrm{a}$ & $448.8 \mathrm{a}$ \\
INR7 & $67.1 \mathrm{ab}$ & $84.1 \mathrm{bc}$ & $348.1 \mathrm{abc}$ \\
ME1 & $33.0 \mathrm{c}$ & $70.8 \mathrm{c}$ & $337.1 \mathrm{abc}$ \\
GB03 & $72.6 \mathrm{a}$ & $102.5 \mathrm{~b}$ & $301.1 \mathrm{bcd}$ \\
INR7 + ME1 & $45.9 \mathrm{abc}$ & $77.1 \mathrm{c}$ & $249.3 \mathrm{~cd}$ \\
INR7 + GB03 & $33.5 \mathrm{c}$ & $83.9 \mathrm{bc}$ & $270.0 \mathrm{~cd}$ \\
INR7 + ME1 + GB03 & $69.8 \mathrm{a}$ & $80.3 \mathrm{c}$ & $271.5 \mathrm{~cd}$ \\
ISR control & $37.6 \mathrm{bc}$ & $12.3 \mathrm{~d}$ & $396.3 \mathrm{ab}$ \\
Healthy control & $0.0 \mathrm{~d}$ & $0.0 \mathrm{~d}$ & $0.0 \mathrm{e}$ \\
LSD & 31.4 & 18.7 & 112.4 \\
\hline
\end{tabular}

${ }^{\mathrm{v}}$ Experiments were repeated three times. One representative trial is presented for each pathogen.

w PGPR strains applied as seed treatments are INR7 (Bacillus pumilus), ME1 (Curtobacterium flaccumfaciens), and GB03 (B. subtilis). Controls included a nonbacterized but pathogen-challenged disease control, a nontreated healthy control, and a classical induced systemic resistance (ISR) control, in which plant resistance was induced with the pathogen $C$. orbiculare on the cotyledons 7 days prior to pathogen challenge.

${ }^{x}$ Values for $C$. orbiculare or $P$. syringae pv. lachrymans represent the sum of percent diseased leaf area of the second and third leaf of each cucumber plant from eight replications per treatment.

y Values represent calculated area under disease progress curves of the number of wilted leaves per total leaf number of each plant from eight replications per treatment recorded over 7 consecutive observation days.

${ }^{\mathrm{z}}$ Means followed by different letters are significantly different according to the protected least significant difference (LSD) test at $P=0.05$ using the general linear models procedure in PC-SAS.

TABLE 2. Disease protection induced by three plant growth-promoting rhizobacteria (PGPR) strains and their mixtures after double-pathogen challenge of cucumber plants under greenhouse conditions ${ }^{\mathrm{u}}$

\begin{tabular}{|c|c|c|c|}
\hline Treatments ${ }^{v}$ & $\begin{array}{c}\text { Colletotrichum. } \\
\text { orbiculare }+ \\
\text { Pseudomonas syringae } \\
\text { pv. lachrymans }{ }^{\mathrm{w}}\end{array}$ & $\begin{array}{l}\text { C. orbiculare } \\
\quad+\text { Erwina } \\
\text { tracheiphila }\end{array}$ & $\begin{array}{l}\text { E. tracheiphila }+ \\
\text { P. syringae pv. } \\
\text { lachrymans }^{\mathrm{y}}\end{array}$ \\
\hline Disease control & $170.9 \mathrm{a}^{\mathrm{z}}$ & $194.1 \mathrm{a}$ & $615.3 \mathrm{ab}$ \\
\hline INR7 & $141.0 \mathrm{~b}$ & $192.4 \mathrm{ab}$ & $641.0 \mathrm{a}$ \\
\hline ME1 & $123.1 \mathrm{bc}$ & $186.5 \mathrm{ab}$ & $568.5 \mathrm{abc}$ \\
\hline GB03 & $133.9 \mathrm{bc}$ & $187.9 \mathrm{ab}$ & 499.6 abcd \\
\hline INR7 + ME1 & $121.0 \mathrm{c}$ & $173.6 \mathrm{bc}$ & $428.1 \mathrm{~cd}$ \\
\hline INR7 + GB03 & $126.4 \mathrm{bc}$ & $165.4 \mathrm{c}$ & $434.6 \mathrm{~cd}$ \\
\hline INR7 + ME1 + GB03 & $131.3 \mathrm{bc}$ & $185.1 \mathrm{ab}$ & $385.0 \mathrm{~d}$ \\
\hline ISR control & $86.9 \mathrm{~d}$ & $98.8 \mathrm{~d}$ & $502.2 \mathrm{abcd}$ \\
\hline Healthy control & $0.0 \mathrm{e}$ & $0.0 \mathrm{e}$ & $0.0 \mathrm{e}$ \\
\hline $\mathrm{LSD}^{\mathrm{z}}$ & 19.5 & 19.2 & 157.3 \\
\hline
\end{tabular}

u Experiments were repeated three times. One representative trial is presented for each pathogen combination.

${ }^{\vee}$ PGPR strains applied as seed treatments are INR7 (Bacillus pumilus), ME1 (Curtobacterium flaccumfaciens), and GB03 (B. subtilis). Controls included a nonbacterized but pathogen-challenged disease control, a nontreated healthy control, and a classical induced systemic resistance (ISR) control, in which plant resistance was induced with the pathogen $C$. orbiculare on the cotyledons 7 days prior to challenge.

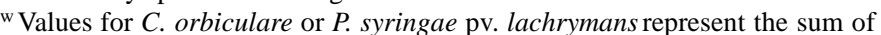
percent diseased leaf area of the second and third leaf of each cucumber plant from eight replications per treatment.

${ }^{x}$ Bacterial wilt did not develop because of the very severe expression of anthracnose; values represent the sum of percent diseased leaf area of the second and third leaf of each plant caused by $C$. orbiculare. Presented are the mean of eight replications of each treatment.

${ }^{y}$ Bacterial leaf spot disease did not develop (less than 5\% diseased leaf area); values represent calculated area under disease progress curves of the number of wilted leaves per total leaf number of each plant from eight replications per treatment over 9 consecutive observation days.

${ }^{z}$ Means followed by different letters are significantly different according to the protected least significant difference (LSD) test at $P=0.05$ using the general linear models procedure in PC-SAS. scale from 0 to 5 , in which $0=$ no lesions, $1=1$ to $20 \%$ of leaf area with lesions, $2=20$ to $40 \%$ of leaf area with lesions, $3=40$ to $60 \%$ of leaf area with lesions, $4=60$ to $80 \%$ of leaf area with lesions, and $5=80$ to $100 \%$ of leaf area with lesions. With this scale, the percentage of leaf area with lesions reflected the combined severity of anthracnose and angular leaf spot, both of which occurred in 1997. Data were analyzed using analysis of variance with GLM in PC-SAS, and treatment means were separated by the LSD test at $P=0.05$ with PC-SAS.

\section{RESULTS}

Greenhouse study. The background level of disease obtained in the disease control treatment varied among the three trials of each experiment; however, the same trends for treatment effects on disease occurred in all three trials. Data in Tables 1 to 3 are from one representative trial of the three trials of each experiment. PGPR treatments induced significant disease protection compared with the noninduced disease control to varying degrees against $C$. orbiculare, P. syringae pv. lachrymans, and E. tracheiphila (Table 1). The frequency with which various PGPR treatments induced significant protection varied with the pathogen used. Against $C$. orbiculare and E. tracheiphila, one of the three tested PGPR strains applied individually induced significant reductions of symptoms compared with the disease control, while all three individual strain treatments significantly reduced symptoms of $P$. syringae pv. lachrymans (Table 1). The number of strain mixtures that induced significant protection was the same as the number of individual strains that significantly reduced symptoms of $C$. orbiculare and $P$. syringae pv. lachrymans, but was greater for E. tracheiphila (Table 1). The classical ISR control, in which plants were induced by inoculating the cotyledons with the pathogen $C$. orbiculare 7 days prior to challenge with the same pathogen, significantly reduced symptoms of $C$. orbiculare and $P$. syringae pv. lachrymans, but not $E$. tracheiphila.

TABLE 3. Disease protection induced by three plant growth-promoting rhizobacteria (PGPR) strains and their mixtures after triple-pathogen challenge of cucumber plants under greenhouse conditions ${ }^{\mathrm{u}}$

\begin{tabular}{lcc}
\hline & $\begin{array}{c}\text { Colletotrichum orbiculare + Pseudomonas syringae } \\
\text { pv. lachrymans }+ \text { Erwina tracheiphila }\end{array}$ \\
\cline { 2 - 3 } Treatments $^{\mathrm{v}}$ & Diseased leaf area $^{\mathrm{w}}$ & Live plants $^{\mathrm{x}}$ \\
\hline Disease control & $93.1 \mathrm{a}^{\mathrm{y}}$ & 0.0 \\
INR7 & $72.5 \mathrm{~b}$ & 37.5 \\
ME1 & $61.9 \mathrm{bc}$ & 0.0 \\
GB03 & $52.5 \mathrm{~cd}$ & 0.0 \\
INR7 + ME1 & $54.8 \mathrm{~cd}$ & 37.5 \\
INR7 + GB03 & $49.0 \mathrm{~cd}$ & 25.0 \\
INR7 + ME1 + GB03 & $38.6 \mathrm{~d}$ & 25.0 \\
ISR control & $10.6 \mathrm{e}$ & 0.0 \\
Healthy control & $0.0 \mathrm{e}$ & 100.0 \\
LSD & 16.7 & $\mathrm{nd}^{\mathrm{z}}$
\end{tabular}

u Experiments were repeated three times. One representative trial is presented.

v PGPR strains applied as seed treatments are INR7 (Bacillus pumilus), ME1 (Curtobacterium flaccumfaciens), and GB03 (B. subtilis). Controls included a nonbacterized but pathogen-challenged disease control, a nontreated healthy control, and a classical induced systemic resistance (ISR) control, in which plant resistance was induced with the pathogen $C$. orbiculare on the cotyledons 7 days prior to challenge.

${ }^{\text {w }}$ Values represent the sum of percent diseased leaf area caused by $C$. orbiculare and P. syringae pv. lachrymans of the second and third leaf of each cucumber plant from eight replications per treatment.

${ }^{\mathrm{x}}$ Bacterial wilt was assessed as the percent of live plants 21 days after challenge, because typical progressive wilt symptoms did not develop after challenging with three pathogens.

${ }^{y}$ Means followed by different letters are significantly different according to the protected least significant difference (LSD) test at $P=0.05$ using the general linear models procedure in PC-SAS.

${ }^{\mathrm{z}} \mathrm{nd}=$ not determined. 
In the series of experiments in which plants were inoculated with two pathogens at the same time (Table 2), there was a trend to greater control with mixtures of strains. When the challenge pathogens were $C$. orbiculare and $P$. syringae pv. lachrymans, typical symptoms of both anthracnose and angular leaf spot resulted, and significant protection, relative to the noninduced disease control, was induced with all three individually applied PGPR as well as all strain mixtures. When challenged with both $C$. orbiculare and E. tracheiphila, anthracnose lesions developed within 5 to 6 days after pathogen inoculation. However, wilt symptoms were not observed and, therefore, results of only anthracnose symptoms were evaluated. With $P$. syringae pv. lachrymans and E. tracheiphila as the pathogens, angular leaf spot caused less than 5\% mean diseased leaf area across all three repeated trials, so only wilt disease was measured as AUDPC values. In both these cases in which only one pathogen caused disease after a double-pathogen challenge (Table 2, columns 2 and 3), significant treatment effects were only detected with PGPR mixtures and not with individual strains.

In the three-way challenge of pathogens (Table 3), typical symptoms of anthracnose and angular leaf spot developed. Symptoms typical of cucurbit wilt (progressive wilting of whole plants starting with a single leaf at 10 to 14 days after inoculation) were not observed, and affected plants showed rapid total collapse and death at 18 to 20 days after inoculation, so wilt was evaluated by recording numbers of live or dead plants 21 days after challenge (Table 3). Results in Table 3, therefore, are given as two disease measurements; the first value represents the percentage of diseased leaf area caused by the two inoculated leaf pathogens rated 7 days after challenge, and the second value indicates the survival rate of plants 21 days after challenge. Significant reductions in diseased leaf area were induced by all three individual PGPR strains as well as all strain mixtures. The magnitude of protection was greater with strain mixtures than with individual strains. Reductions in symptoms of E. tracheiphila as measured by an increased percentage of live plants compared with the noninduced disease control were only detected with one of the three individual PGPR treatments, while all three strain mixtures induced reductions in symptoms. As in the experiments with single or double pathogen inoculations (Tables 1 and 2), induction with $C$. orbiculare did not lead to a reduction in symptoms of E. tracheiphila.

Overall, in seven different experiments repeated three times, mixtures consisting of two or three strains showed slightly greater levels of disease suppression as compared with single PGPR strains (Table 4). Means of disease reductions were $26.2 \%$ for mixtures and $21.7 \%$ for single strains. In addition, the consistency of obtaining significant disease suppression by PGPR treatments was increased with mixtures as compared with single strain treatments; mixtures induced significant disease sup- pression in 12.3 trials, while single strains induced significant suppression in 8.7 of the 21 total trials.

Field trials. Although inocula of $C$. orbiculare, $P$. syringae pv. lachrymans, and E. tracheiphila were applied to source plants placed into challenged experimental plots, angular leaf spot was the predominant disease occurring in the 1996 field trial. All PGPR treatments significantly reduced the number of infected leaves with angular leaf spot in plots with and without the source plants (Table 5). The greatest level of disease suppression with and without source plants resulted with the treatment containing the three-strain mixture of PGPR. There were generally no statistically significant effects on yield in this trial, except for the combination INR7 plus ME1 under high disease pressure (Table 5).

In the field trial in 1997 (Table 6), all treatments led to significant increases in plant growth as measured by the length of the main runner 43 days after planting, but there were differences among

TABLE 5. Effects of individual plant growth-promoting rhizobacteria (PGPR) strains and strain mixtures on yield and severity of angular leaf spot disease at two inoculum potentials in the field in $1996^{\mathrm{u}}$

\begin{tabular}{|c|c|c|c|c|}
\hline \multirow[b]{2}{*}{ Treatment $^{\mathrm{v}}$} & \multicolumn{2}{|c|}{ Natural field infestation } & \multicolumn{2}{|c|}{$\begin{array}{l}\text { High inoculum potential } \\
\text { by infected source plants }\end{array}$} \\
\hline & $\begin{array}{l}\text { Angular } \\
\text { leaf spot }\end{array}$ & $\begin{array}{l}\text { Marketable } \\
\text { yield }(\mathrm{kg})^{\mathrm{y}}\end{array}$ & $\begin{array}{l}\text { Angular } \\
\text { leaf spot }\end{array}$ & $\begin{array}{l}\text { Marketable } \\
\text { yield }(\mathrm{kg})^{\mathrm{y}}\end{array}$ \\
\hline Control & $23.0 \mathrm{a}^{\mathrm{z}}$ & $13.5 \mathrm{a}$ & $43.7 \mathrm{a}$ & $13.8 \mathrm{~b}$ \\
\hline INR7 & $7.1 \mathrm{bcd}$ & $15.7 \mathrm{a}$ & $16.5 \mathrm{bcd}$ & $13.9 \mathrm{~b}$ \\
\hline ME1 & $12.3 \mathrm{~b}$ & $16.2 \mathrm{a}$ & $20.8 \mathrm{bc}$ & $11.7 \mathrm{~b}$ \\
\hline GB03 & $11.1 \mathrm{bc}$ & $16.0 \mathrm{a}$ & $19.8 \mathrm{bcd}$ & $15.7 \mathrm{ab}$ \\
\hline INR7 + ME1 & $4.6 \mathrm{~cd}$ & $14.6 \mathrm{a}$ & $12.0 \mathrm{~cd}$ & $18.0 \mathrm{a}$ \\
\hline INR7 + GB03 & $7.6 \mathrm{bcd}$ & $13.9 \mathrm{a}$ & $14.2 \mathrm{bcd}$ & $15.6 \mathrm{ab}$ \\
\hline $\mathrm{ME} 1+\mathrm{GB} 03$ & $11.5 \mathrm{bc}$ & $17.1 \mathrm{a}$ & $25.0 \mathrm{~b}$ & $15.1 \mathrm{ab}$ \\
\hline INR7 + ME1 + GB03 & $3.3 \mathrm{c}$ & $17.1 \mathrm{a}$ & $8.4 \mathrm{~d}$ & $13.7 \mathrm{~b}$ \\
\hline LSD & 6.9 & 5.1 & 12.1 & 4.1 \\
\hline
\end{tabular}

u The field trial was conducted as a randomized complete block with two pairs of plots (with and without source plants), each with eight treatments, six replications per treatment, and eight plants per replication.

v PGPR strains applied as a seed treatment are INR7 (Bacillus pumilus), ME1 (Curtobacterium flaccumfaciens), and GB03 (B. subtilis).

wSource plants were infected in the greenhouse with either Colletotrichum orbiculare and Pseudomonas syringae pv. lachrymans or with Erwina tracheiphila before two of each set of plants were placed into every paired experimental plot as 3-week-old transplants. Disease ratings are based on angular leaf spot, which was the predominant disease expressed in the field in 1996.

$x$ Number of leaves with more than five lesions per leaf were counted, and presented are means of six replications each with eight plants per treatment.

y Cucumber were picked twice a week as marketable fruits until the end of the season, and presented are cumulative mean yields per treatment.

${ }^{\mathrm{z}}$ Numbers with different letters are showing significant differences at $P=0.05$ according to the least significant difference (LSD) test procedure using the general linear models procedure in PC-SAS.

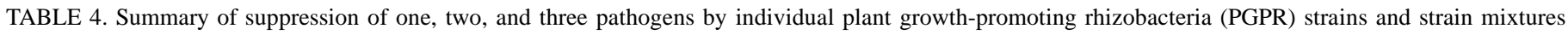
over three repeated trials ${ }^{\mathrm{v}}$

\begin{tabular}{|c|c|c|c|c|c|c|c|c|c|}
\hline \multirow[b]{2}{*}{ Treatment $^{\mathrm{w}}$} & \multicolumn{7}{|c|}{ Mean percentage of disease reduction (number of significant trials) ${ }^{\mathrm{x}}$} & \multirow[b]{2}{*}{ Total mean ${ }^{\mathrm{z}}$} & \multirow[b]{2}{*}{ Total significant trials } \\
\hline & $\mathrm{C}^{\mathrm{y}}$ & $\mathrm{P}^{\mathrm{y}}$ & $\mathrm{E}^{\mathrm{y}}$ & $\mathrm{C}+\mathrm{P}$ & $\mathrm{C}+\mathrm{E}$ & $\mathrm{P}+\mathrm{E}$ & $C+P+E$ & & \\
\hline $\mathrm{I}+\mathrm{M}+\mathrm{G}$ & $25.7(1)$ & $48.4(3)$ & $40.8(3)$ & $9.8(1)$ & $5.5(1)$ & $31.3(1)$ & $21.6(1)$ & 26.2 & 11 \\
\hline $\mathrm{I}+\mathrm{M}$ & $44.0(2)$ & $43.1(2)$ & $33.2(2)$ & $18.5(2)$ & $5.5(1)$ & $17.9(1)$ & $22.7(2)$ & 26.4 & 12 \\
\hline $\mathrm{I}+\mathrm{G}$ & $39.0(2)$ & $37.2(2)$ & $38.1(3)$ & $12.7(1)$ & $8.7(2)$ & $27.1(2)$ & $20.1(2)$ & 26.1 & 14 \\
\hline M & $40.2(2)$ & $36.2(2)$ & 31.7 (1) & $13.1(1)$ & $3.4(0)$ & $10.9(0)$ & $36.3(3)$ & 24.5 & 9 \\
\hline $\mathrm{G}$ & $43.7(2)$ & $14.7(2)$ & $16.1(1)$ & $10.8(2)$ & $0.5(0)$ & $33.0(1)$ & $34.0(2)$ & 21.8 & 10 \\
\hline I & $21.5(0)$ & 35.9 (2) & $27.4(1)$ & $9.9(1)$ & $2.3(0)$ & $9.5(0)$ & $25.2(3)$ & 18.8 & 7 \\
\hline ISR control & $68.4(3)$ & $69.8(3)$ & $18.4(0)$ & $59.8(3)$ & $43.7(3)$ & $-0.4(0)$ & $83.8(3)$ & 49.1 & 15 \\
\hline
\end{tabular}

v Summary of results from 21 greenhouse experiments (seven different pathogen challenges each with three trials).

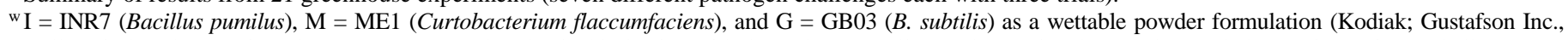
Dallas); induced systemic resistance (ISR) control = classical induction with the pathogen Colletotrichum orbiculare on the cotyledons 7 days prior to challenge.

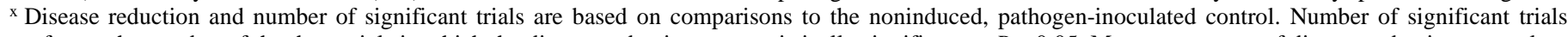
refers to the number of the three trials in which the disease reduction was statistically significant at $P=0.05$. Mean percentage of disease reduction was calculated by averaging the percentage of disease reduction from each of the three trials.

y $\mathrm{C}=$ Colletotrichum orbiculare, $\mathrm{P}=$ Pseudomonas syringae pv. lachrymans, and $\mathrm{E}=$ Erwinia tracheiphila .

$\mathrm{z}$ Total mean represents the average (percent) disease reduction of treatments over all 21 conducted trials. 
the treatments in the magnitude of growth promotion. The least significant growth promotion occurred with the Actigard treatment, which was significantly less than the growth promotion that resulted from treatment with strain INR7 as a seed treatment or foliar spray and from seed treatment with mixtures of strains (INR7 plus IN26; and INR7 plus ME1 plus GB03) (Table 6). Cucurbit wilt disease did not occur in 1997 due to the lack of the beetle vectors necessary to transmit the pathogen E. tracheiphila from the source plants. Consequently, disease assessments 49 DAP were based on the combined incidence of anthracnose and angular leaf spot using the 0 to 5 rating scale. All treatments led to significant disease suppression compared with the noninduced control, and there were significant differences in the magnitude of suppression among the PGPR treatments. Both strains IN26 and INR7 significantly suppressed disease when applied as seed treatments or foliar sprays, and with each application method, INR7 induced a significantly greater level of suppression than did IN26 (Table 6). The greatest magnitude of disease suppression occurred with Actigard, and the suppression resulting from seed treatment with the three-strain PGPR mixture was equivalent to the suppression from Actigard. The three-way PGPR strain mixture consisting of INR7, ME1, and GB03 provided control at a level statistically equivalent to the control by Actigard (Table 6). PGPR strain INR7 significantly reduced disease both as a seed treatment and as a spray application applied four times at weekly intervals.

\section{DISCUSSION}

Results presented here demonstrate that individual PGPR treatments induced significant disease protection against three pathogens inoculated individually and in two- or three-pathogen combinations and that mixtures of these PGPR strains exhibited a general trend toward greater disease suppression and more consistent obtainment of significant disease suppression. In the summary of all 21 greenhouse trials (Table 4), treatments with the three single PGPR strains resulted in significant disease suppression as compared with the noninduced control in 7, 9, and 10 trials, while the three mixtures of PGPR led to significant protection in 11, 12, and 14 trials. Different mechanisms of action for different PGPR strains may explain why combinations of strains provided more consis-

TABLE 6. Effects of individual plant growth-promoting rhizobacteria (PGPR) strains and strain mixtures on plant growth promotion and severity of anthracnose and angular leaf spot using artificially infected source plants in the field in 1997

\begin{tabular}{lcc}
\hline Treatment $^{\mathrm{w}}$ & $\begin{array}{c}\text { Mean main runner } \\
\text { length }(\mathrm{cm})^{\mathrm{x}}\end{array}$ & $\begin{array}{c}\text { Anthracnose and angular } \\
\text { leaf spot (disease index) }\end{array}$ \\
\hline Control & $44.8 \mathrm{~d}^{\mathrm{z}}$ & $3.23 \mathrm{a}$ \\
INR7 & $71.3 \mathrm{ab}$ & $1.68 \mathrm{~cd}$ \\
IN26 & $64.1 \mathrm{bc}$ & $2.39 \mathrm{~b}$ \\
INR7 + IN26 & $74.2 \mathrm{a}$ & $1.78 \mathrm{~cd}$ \\
INR7 + ME1 + GB03 & $72.0 \mathrm{ab}$ & $1.47 \mathrm{de}$ \\
INR7 spray & $72.2 \mathrm{ab}$ & $1.91 \mathrm{c}$ \\
IN26 spray & $60.0 \mathrm{bc}$ & $2.34 \mathrm{~b}$ \\
Actigard & $61.6 \mathrm{c}$ & $1.24 \mathrm{e}$ \\
LSD & 8.98 & 0.33 \\
\hline
\end{tabular}

${ }^{\mathrm{w}}$ Strains INR7 (Bacillus pumilus) and IN26 (Burkholderia gladioli) were coated onto cucumber seeds alone or in combination, or sprayed onto field plants four times at weekly intervals. Strains INR7, ME1 (Curtobacterium flaccumfaciens), and GB03 (Bacillus subtilis) were applied as a seed treatment mixture. The commercial elicitor product Actigard (Novartis Crop Protection, Inc., Basel, Switzerland) was used as a spray application four times at weekly intervals.

${ }^{x}$ Mean main runner length in centimeters was measured 43 days after planting.

${ }^{y}$ Disease assessment was done 49 days after planting the field by direct seeding according to a disease rating scale from 0 to $5(0=$ healthy to $5=$ dead) based on the degree of disease infestation per plant.

${ }^{\mathrm{z}}$ Means followed by different letters are significantly different according to the protected least significant difference (LSD) test at $P=0.05$ using the general linear models procedure in PC-SAS. tency in disease suppression. These results are in agreement with studies by Pierson and Weller (33) and Duffy and Weller (12), both of which demonstrated that certain mixtures of fluorescent pseudomonads were significantly more suppressive of take-all than either treatment used alone. Sung and Chung (42) demonstrated that chitinase-producing Streptomyces spp. and Bacillus cereus isolates used in conjunction with antibiotic-producing $P$. fluorescens and Burkholderia (Pseudomonas) cepacia isolates had a synergistic effect on the suppression of rice sheath blight. Because of the horizontal type of resistance associated with ISR (27), PGPR strains with ISR activity may increase the probability of achieving disease suppression against a wider range of pathogens compared with antagonists with antibiotic production as the main mechanism of biocontrol (23). Although the use of C. orbiculare (classical ISR control) proved to be a successful method to induce systemic resistance to anthracnose and angular leaf spot, the use of pathogens as inducers would not be practical agronomically because of the potential spread of disease. In addition, the classical ISR control failed to induce significant suppression of cucurbit wilt, and this occurred only with PGPR treatments.

The two field experiments in 1996 and 1997 investigating several different PGPR treatments demonstrated the feasibility of inducing resistance in cucumber plants under conditions of high inoculum potential (Tables 5 and 6). The comparison to Actigard indicated that some PGPR strains were as effective as this commercially available elicitor. The fact that a single application of PGPR strains as a seed treatment provided significant disease reduction through ISR in the field is particularly encouraging for the use of PGPR as components of integrated pest management systems. Other means of activating disease resistance (e.g., chemical inducers like Actigard applied as a spray) might require several applications, each of which would add costs for foliar spray application and would be dependent on favorable weather. Further, seed treatments provide targeted application of PGPR, allowing earlier protection than could be provided with foliar sprays. In addition, the additional plant growth promotion provided by some PGPR treatments in comparison to Actigard (Table 6) adds another advantage to PGPR over chemical inducers.

The still very limited number of compatible and effective mixtures of biocontrol agents is due to several factors. The majority of mixtures have no benefit or are detrimental to biocontrol activity. Further, a mixture that improves activity under one set of conditions or on one host may be antagonistic under another set of conditions or on a different host. From an economical point of view, a biocontrol product composed of a mixture of strains has a potential drawback, because producing and registering such a product will likely be more costly than a product composed of a single strain (39). However, greater emphasis on developing mixtures of biocontrol agents is needed, because they may result in better plant colonization, be better adapted to the environmental changes that occur throughout the growing season, present a larger number of pathogen-suppressive mechanisms, or protect against a broader range of pathogens (1).

Mixtures of biocontrol agents without chemical pesticides, as demonstrated in this study, will be of interest to the growing organic crop industry (in which, in order to be certified as organic, producers cannot use pesticides). For conventional agriculture, however, combinations of biological and chemical control seem to be the most promising area for the near future. Conway (6) reported that Laetisaria arvalis and a foliar spray of the experimental fungicide CGA 173506 at one-half the recommended rate reduced disease on rosemary more than treatment with either the biocontrol agent or fungicide alone. Commercial development has already been accomplished with two products marketed as Kodiak and Epic (Gustafson Inc.), in which two different Bacillus subtilis biocontrol strains were combined with a fungicide (carboxin-PCNB-metalaxyl) for use against soilborne diseases. During the 1996 season, approximately 5 million ha of crops were treated with these products, targeting 
diseases of roots caused by Rhizoctonia solani and Fusarium spp., plus promoting increased root mass and plant vigor through horone-like responses and disease control (1).

The results presented here indicate that mixtures of PGPR strains can enhance disease protection and improve the consistency of biological control. Therefore, it is essential to investigate microbial interactions that enhance or detract from biocontrol (16) to understand and predict the performance of mixtures of specific biocontrol agents.

\section{ACKNOWLEDGMENTS}

This research was supported by USDA NRI grant 9437312-0625.

\section{LITERATURE CITED}

1. Backman, P. A., Wilson, M., and Murphy, J. F. 1997. Bacteria for biological control of plant diseases. Pages 95-109 in: Environmentally Safe Approaches to Crop Disease Control. N. A. Rechcigl and J. E. Rechcigl, eds. CRC Lewis Publishers, Boca Raton, FL.

2. Baker, R. 1990. An overview of current and future strategies and models for biological control. Pages 375-388 in: Biological Control of Soilborne Plant Pathogens. D. Hornby, ed. CAB International, Wallingford, United Kingdom.

3. Baker, R. 1991. Diversity in biological control. Crop Prot. 10:85-94.

4. Boeger, J. M., Chen, R. S., and McDonald, B. 1993. Gene flow between geographic populations of Mycosphaerella graminicola (anamorph Septoria tritici) detected with restriction fragment length polymorphism markers. Phytopathology 83:1148-1154.

5. Budge, S. P., McQuilken, M. P., Fenlon, J. S., and Whipps, J. M. 1995. Use of Coniothyrium minitans and Gliocladium virens for biological control of Sclerotinia sclerotiorum in glasshouse lettuce. Biol. Control 5:513-522.

6. Conway, K. E. 1997. Integration of biological and chemical controls for Rhizoctonia aerial blight and root rot of rosemary. Plant Dis. 81:795-798.

7. Dandurand, L. M., and Knudsen, G. R. 1993. Influence of Pseudomonas fluorescens on hyphal growth and biocontrol activity of Trichoderma harzianum in the spermoshere and rhizosphere of pea. Phytopathology 83:265-270.

8. Datnoff, L. E., Nemec, S., and Pernezny, K. 1995. Biological control of Fusarium crown and root rot of tomato in Florida using Trichoderma harzianum and Glomus intraradices. Biol. Control 5:427-431.

9. Datnoff, L. E., Nemec, S., and Pohronezny, K. 1993. Influence of Trichoderma harzianum and Glomus intraradices on incidence and severity of Fusarium crown and root rot. Biol. Cultural Tests 9:78.

10. De Boer, M., van der Sluis, I., van Loon, L. C., and Bakker, P. A. H. M. 1997. In vitro compatibility between fluorescent Pseudomonas spp. strains can increase effectivity of Fusarium wilt control by combinations of these strains. Pages 380-382 in: Plant Growth-Promoting Rhizobacteria—Present Status and Future Prospects. Proc. Int. Workshop on Plant Growth-Promoting Rhizobacteria, 4th. A. Ogoshi, K. Kobayashi, Y. Homma, F. Kodama, N. Kondo, and S. Akino, eds. Nakanishi Printing, Sapporo, Japan.

11. Duffy, B. K., Simon, A., and Weller, D. M. 1996. Combination of Trichoderma koningii with fluorescent pseudomonads for control of take-all on wheat. Phytopathology 86:188-194.

12. Duffy, B. K., and Weller, D. M. 1995. Use of Gaeumannomyces graminis var. graminis alone and in combination with fluorescent Pseudomonas spp. to suppress take-all of wheat. Plant Dis. 79:907-911.

13. Fry, W. E., Goodwin, S. R., Matuszak, J. M., Spielman, L. J., and Milgroom, M. G. 1992. Population genetics and intercontinental migrations of Phytophthora infestans. Annu. Rev. Phytopathol. 30:107-129.

14. Goode, M. J. 1958. Physiological specialization in Colletotrichum lagenarium. Phytopathology 48:79-83.

15. Hall, R. 1995. Challenges and prospects of integrated pest management. Pages 1-21 in: Novel Approaches to Integrated Pest Management. R. Reuveni, ed. Lewis Publishers, CRC Press, Inc., Boca Raton, FL.

16. Handelsman, J., and Stabb, E. V. 1996. Biocontrol of soilborne plant pathogens. Plant Cell 8:1855-1869.

17. Hassan, D. G., Zargar, M., and Beigh, G. M. 1997. Biocontrol of Fusarium root rot in the common bean (Phaseolus vulgaris L.) by using symbiotic Glomus mosseae and Rhizobium leguminosarum. Mol. Ecol. 34:74-80.

18. Hubbard, J. P., Harman, G. E., and Hadar, Y. 1983. Effect of soilborne Pseudomonas spp. on the biological control agent, Trichoderma hamatum, on pea seeds. Phytopathology 73:655-659.

19. Janisiewicz, W. J. 1988. Biocontrol of postharvest diseases of apples with antagonist mixtures. Phytopathology 78:194-198.

20. Janisiewicz, W. J. 1996. Ecological diversity, niche overlap, and coexis- tence of antagonists used in developing mixtures for biocontrol of postharvest diseases of apples. Pytopathology 86:473-479.

21. Janisiewicz, W. J., and Bors, B. 1995. Development of a microbial community of bacterial and yeast antagonists to control wound-invading postharvest pathogens of fruits. Appl. Environ. Microbiol. 61: 3261-3267.

22. Johnson, K. B., Stockwell, V. O., McLaughlin, R. J., Sugar, D., Loper, J. E., and Roberts, R. G. 1993. Effect of antagonistic bacteria on establishment of honey bee-dispersed Erwinia amylovora in pear blossoms and on fire blight control. Phytopathology 83:995-1002.

23. Kloepper, J. W., Zehnder, G. W., Tuzun, S., Murphy, J. F., Wei, G., Yao, C., and Raupach, G. S. 1996. Toward agricultural implementation of PGPRmediated induced systemic resistance against crop pests. Pages 165-174 in: Advances in Biological Control of Plant Diseases. T. Wenhua, R. J. Cook, and A. Rovira, eds. China Agricultural University Press, Beijing.

24. Leeman, M., den Ouden, F. M., van Pelt, J. A., Cornellissen, C., MatamalaGarros, A., Bakker, P. A. H. M., and Schippers, B. 1996. Suppression of fusarium wilt of radish by co-inoculation of fluorescent Pseudomonas spp. and root-colonizing fungi. Eur. J. Plant Pathol. 102:21-31.

25. Leibinger, W., Beuker, B., Hahn, M., and Mendgen, K. 1997. Control of postharvest pathogens and colonization of the apple surface by antagonistic microorganisms in the field. Phytopathology 87:1103-1110.

26. Lemanceau, P., and Alabouvette, C. 1991. Biological control of fusarium diseases by fluorescent Pseudomonas and nonpathogenic Fusarium. Crop Prot. 10:279-286.

27. Lyon, G. D., and Newton, A. C. 1997. Do resistance elicitors offer new opportunities in integrated disease control strategies? Plant Pathol. 46: 636-641.

28. Mazzola, M., Fujimoto, D. K., Thomashow, L. S., and Cook, R. J. 1995. Variation in sensitivity of Gaeumannomyces graminis to antibiotics produced by fluorescent Pseudomonas spp. and effect on biological control of take-all of wheat. Appl. Environ. Microbiol. 61:2554-2559.

29. McDonald, B. A., Miles, A. J., Nelson, L. R., and Pettway, R. E. 1994. Genetic variability in nuclear DNA in field populations of Stagonospora nodorum. Phytopathology 84:250-255.

30. Miller, R. H., and May, S. 1991. Legume inoculation: Successes and failures. Pages 123-134 in: The Rhizosphere and Plant Growth. D. L. Keister and P. B. Cregan, eds. Kluwer Academic Publishers, Dordrecht, the Netherlands.

31. Park, C., Paulitz, T. C., and Baker, R. 1988. Biocontrol of Fusarium wilt of cucumber resulting from interactions between Pseudomonas putida and nonpathogenic isolates of Fusarium oxysporum. Phytopathology 78:190-194.

32. Paulitz, T. C., Ahmad, J. S., and Baker, R. 1990. Integration of Pythium nunn and Trichoderma harzianum isolate T-95 for the biological control of Pythium damping-off of cucumber. Plant Soil 121:243-250.

33. Pierson, E. A., and Weller, D. M. 1994. Use of mixtures of fluorescent pseudomonads to suppress take-all and improve the growth of wheat. Phytopathology 84:940-947.

34. Raaijmakers, J. M., van der Sluis, I., Koster, M., Bakker, P. A. H. M., Weisbeek, P. J., and Schippers, B. 1995. Utilization of heterologous siderophores and rhizosphere competence of fluorescent Pseudomonas spp. Can. J. Microbiol. 41:126-135.

35. Raupach, G. S., Liu, L., Murphy, J. F., Tuzun, S., and Kloepper, J. W. 1996. Induced systemic resistance in cucumber and tomato against cucumber mosaic cucumovirus using plant growth-promoting rhizobacteria (PGPR). Plant Dis. 80:891-894.

36. Reuveni, R. 1995. Novel Approaches to Integrated Pest Management. Lewis Publishers, Boca Raton, FL.

37. Roberts, D. P., Dery, P. D., Mao, W., and Hebrar, P. K.1997. Use of a colonization-deficient strain of Escherichia coli in strain combinations for enhanced biocontrol of cucumber seedling diseases. J. Phytopathol. 145:461-463.

38. Schippers, B. 1992. Prospects for management of natural suppressiveness to control soilborne pathogens. Pages 21-34 in: Biological Control of Plant Diseases, Progress and Challenges for the Future. NATO ASI Series A: Life Sciences, Vol. 230. E. C. Tjamos, G. C. Papavizas, and R. J. Cook, eds. Plenum Press, New York.

39. Schisler, D. A., Slininger, P. J., and Bothast, R. J. 1997. Effects of antagonist cell concentration and two-strain mixtures on biological control of Fusarium dry rot of potatoes. Phytopathology 87:177-183.

40. Sneh, B., Dupler, M., Elad, Y., and Baker, R. 1984. Chlamydospore germination of Fusarium oxysporum f. sp. cucumerinum as affected by fluorescent and lytic bacteria from a Fusarium-suppressive soil. Phytopathology 74:1115-1124.

41. Stockwell, V. O., Johnson, K. B., and Loper, J. E. 1996. Compatibility of bacterial antagonists of Erwinia amylovora with antibiotics used to control fire blight. Phytopathology 86:834-840.

42. Sung, K. C., and Chung, Y. R. 1997. Enhanced suppression of rice sheath 
blight using combination of bacteria which produce chitinases or antibiotics. Pages 370-372 in: Plant Growth-Promoting RhizobacteriaPresent Status and Future Prospects. Proc. Int. Workshop on Plant Growth-Promoting Rhizobacteria, 4th. A. Ogoshi, K. Kobayashi, Y. Homma, F. Kodama, N. Kondo, and S. Akino, eds. Nakanishi Printing, Sapporo, Japan.

43. Tooley, P. W., and Grau, C. R. 1984. Field characterization of rate-reducing resistance to Phytophthora megasperma f. sp. glycinea in soybean. Phytopathology 74:1201-1208.

44. Waechter-Kristensen, B., Gertsson, U. E., Sundin, P., and Serra, G. 1994. Prospects for microbial stabilization in the hydroponic culture of tomato using circulating nutrient solution. Acta Hortic. 361:382-387.
45. Wei, G., Kloepper, J. W., and Tuzun, S. 1996. Induced systemic resistance to cucumber diseases and increased plant growth by plant growth-promoting rhizobacteria under field conditions. Phytopathology 86:221-224.

46. Wei, G., Kloepper, J. W., and Tuzun, S. 1996. Evaluation of induced systemic resistance and plant growth promotion with mixtures of plant growth-promoting rhizobacteria strains in the field. Pages 223-226 in: Advances in Biological Control of Plant Diseases. T. Wenhua, R. J. Cook, and A. Rovira, eds. China Agricultural University Press, Beijing.

47. Wilson, M., and Backman, P. A. Biological control of plant pathogens. In: Handbook of Pest Management. J. R. Ruberson, ed. Marcel Dekker Publishers, New York. In press. 